Bangl. J. Vet. Med. (2007). 5 (1 \& 2): 103-105

\title{
EFFECT OF CERTAIN HAEMATINICS ON BODY WEIGHT AND HAEMATO-BIOCHEMICAL CHANGES IN LABORATORY MICE
}

\author{
M. Jahan*, N. Ahmad and M. Myenuddin \\ Department of Physiology, Faculty of Veterinary Science, Bangladesh Agricultural University, \\ Mymensingh-2202, Bangladesh \\ *Corresponding author’s e-mail address: marefa_1981@yahoo.com
}

\begin{abstract}
A total of 24, six weeks old mice were used to study the body weight and haemato-biochemical changes following administering of different haematinics $\left(\mathrm{CuSO}_{4}, \mathrm{FeSO}_{4}\right.$ and Vitamin $\left.\mathrm{B}_{12}\right)$. The experiment was performed in Physiology laboratory, Department of Physiology, Faculty of Veterinary Science, Bangladesh Agricultural University, Mymensingh, from February to March 2006. They were randomly assigned to one of four equal groups $(n=6)$. In addition to normal rat pellets Group A was supplemented with $\mathrm{CuSO}_{4} @ 0.6 \mathrm{mg} / \mathrm{mice} /$ day orally, Group B with $\mathrm{FeSO}_{4} @ 1.2 \mathrm{mg} / \mathrm{mice} /$ day orally, and Group C with Vitamin $B_{12}$ (Cytamin ${ }^{\circledR}$, Glaxo) @ 0.004mg/mice intramuscularly at every 7 days. Group D was considered as control and was also supplemented with rat pellets. Increased body weight was observed in all haematinic treated mice but group B had a significant $(\mathrm{p}<0.05)$ higher weight gain compared to the control. TEC and PCV increased significantly $(\mathrm{p}<$ $0.05)$ in all the treatment groups compared to the control. Statistically insignificant $(p>0.05)$ increase in TLC was also recorded in all the treated groups. Hb concentration increased for all the treatment groups. The ESR values of the experimental mice were negligible in first hour. The serum transaminases (SGPT and SGOT) increased in all treated groups but the difference in group A was significant $(\mathrm{p}<0.05)$ compared to the control. Blood urea was recorded significantly $(\mathrm{P}<$ 0.01 ) higher for group A and lower for group C compared to the control. This study can be helpful to study the effect of particular haematinic on animal especially on simple stomach animal and human being as mice is used as human and animal model.
\end{abstract}

Key words: Haematinics, haemato-biochemical parameters, mice

\section{INTRODUCTION}

Nutritional anaemia or salt sickness is a common feature causing poor livestock production. Topical forages can rarely satisfy all mineral requirements (Pfander, 1971). Thus suboptimum nutrition is often accepted as the most important limitation to livestock production in tropical countries (McDowell et al., 1983).

Copper is an essential element, necessary for iron utilization and haemoglobin formation (Davis and Mertz, 1987). Copper deficient animals show anaemia, growth disorder, bone malformation, lack of hair pigmentation, diarrhoea, disorders of myelinization and myocardial lesion. Iron is a component of haemoglobin. The end result of iron deficiency is a reduction of haemaglobin synthesis and a deficit of erythrocytes. Microcytic hypochromic anaemia is developed due to iron deficiency. Cobalt, a constituent of Vitamin $\mathrm{B}_{12}$, is essential for the maturation of erythrocyte. Vitamin $\mathrm{B}_{12}$ also stimulates erythropoiesis. Macrocytic normochromic anaemia is developed due to vitamin $\mathrm{B}_{12}$ deficiency (McDonald et al., 1987). Recent studies (Chandra et al., 2000) showed that the supplementation of haematinics $\left(\mathrm{Cu}, \mathrm{Fe}, \mathrm{Co}\right.$, vitamin $\left.\mathrm{B}_{12}\right)$ resulted in the removal of primary causes of nutritional anaemia and subsequent treatment promoted erythropoiesis.

Thus improvement of nutritional status e.g. supply of haematinics ( $\mathrm{Fe}, \mathrm{Cu}$, $\mathrm{Co}$, vitamin $\mathrm{B}_{12}$ ) is supposed to alter the haematological and biochemical paramenters of mice raised under laboratory condition supplied with haematinics. Keeping this in view, the present experiment was designed to study the effect of different haematinics (copper sulphate, ferrous sulphate, vitamin $\mathrm{B}_{12}$ ) on body weight, haematological parameters and biochemical parameters in mice. 


\section{MATERIALS AND METHODS}

A total old twenty four (24), six weeks old mice were randomly assigned to one of four equal groups $(n=6)$. All the groups were fed with rat pellet and additional haematinics were supplied to group A with $\mathrm{CuSO}_{4} @$ $0.6 \mathrm{mg} / \mathrm{mice} /$ day orally, B with $\mathrm{FeSO}_{4} @ 1.2 \mathrm{mg} / \mathrm{mice} /$ day orally and $\mathrm{C}$ with vitamin $\mathrm{B}_{12}$ (Cytamin ${ }^{\circledR}$, Glaxo) @ $0.004 \mathrm{mg} /$ mice intramuscularly at every 7 days for 30 days from February to March 2006 in the laboratory of the Department of Physiology, Faculty of Veterinary Science, Bangladesh Agricultural University, Mymensingh. Group D was considered as control. Pure drinking water was also made available. The body weight of each mouse was measured with the help of electric balance on 7 days interval during the 30 days experimental period. The body weight was taken before feeding in the morning and expressed in gram (g).

Blood samples from 3 mice of each group were collected at the end of experimental period. The mice were starvated overnight. A series of sterile test tubes containing anticoagulant (Double oxalate salt) at a ratio of 1:10 was taken. General anesthesia of mice was done using ether. The blood was collected directly from heart after opening the abdominal and thoracic cavity. The blood was kept in ice bath till examination. Haematological studies such as total erythrocyte count (TEC), total leukocyte count (TLC), estimation of hemoglobin (Hb) by acid hematin method and erythrocyte sedimentation rate (ESR) were performed within two hours of blood collection as described by Lamberg and Rothstein (1977). Rest 3 mice from each group were used for biochemical studies. Blood was collected from tail vein for SGOT, SGPT and urea determination. The samples were analyzed using Reflotron ${ }^{\circledR}$ autoanalyzer (Roche Diagnostics GmbH, D-68298 Mannheim, Germany).

The mean values of the body weight, haematological and biochemical parameters in the different treatment groups were compared with the control by conducting Student’s t-test (Gupta, 1989).

\section{RESULTS AND DISCUSSION}

The body weights were presented in Table 1 . The mean results of different treatment were compared with the control for identifying significant difference. Table 1 revealed that the mean body weight of group B was significantly $(p<0.05)$ higher but in group A and $C$ the increment was gradual but statistically insignificant. The present finding is consistent to Sumati and Kapoor (1986) who reported a significantly higher value for dietary iron treated Wister rats and to Wenzlaf and Erhardt (1991) who observed similar finding in iron dextran treated lambs. This result is partially in agreement with Baustad and Tollersrud (1966) who reported a greater daily weight gain of $4 \%$ in calves supplemented with cobalt and iron dextran compared to control.

Table1. Effect of administration of copper sulphate, ferrous sulphate and vitamin $\mathrm{B}_{12}$ on body weight (g) in mice

\begin{tabular}{|l|llll|}
\hline \multirow{2}{*}{ Days } & Groups $(\mathrm{n}=6)$ & & & \\
\cline { 2 - 5 } & Group A $\left(\mathrm{CuSO}_{4}\right)$ & Group B $\left(\mathrm{FeSO}_{4}\right)$ & Group C (vitamin $\left.\mathrm{B}_{12}\right)$ & Group D (control) \\
\hline Days 0 & $41 \pm 1.03$ & $43.17 \pm 1.74$ & $41.50 \pm 1.09$ & $39.33 \pm 2.56$ \\
Days 7 & $41 \pm 0.89$ & $43.67 \pm 1.43$ & $41.50 \pm 1.06$ & $40 \pm 2.41$ \\
Days 21 & $41.83 \pm 1.58$ & $* 43.83 \pm 0.60$ & $42.67 \pm 1.17$ & $40.67 \pm 0.88$ \\
\hline
\end{tabular}

*indicates significant $(\mathrm{p}<0.05)$ mean difference from control.

$\mathrm{n}=$ Number of mice.

The haematological parameters were presented in Table 2. It was evident that TEC, TLC, Hb and PCV differed in the treatment groups $\mathrm{A}\left(\mathrm{CuSO}_{4}\right), \mathrm{B}\left(\mathrm{FeSO}_{4}\right)$, and $\mathrm{C}\left(\right.$ Vitamin $\left.\mathrm{B}_{12}\right)$ from the control. The ESR values of the experimental mice were negligible in first hour. TEC, TLC, Hb and PCV increased in all treatment groups. TEC and PCV increased significantly $(\mathrm{p}<0.05)$ in treated groups but in case of TLC it was not significant for any groups. An insignificant $(p>0.05)$ rise of $\mathrm{Hb}$ was recorded in the treated groups. This result is in consistent to that of Sumati and Kapoor (1986) who observed an increase in the Hb concentration following supplementation of dietary iron to Wisteer rats. Wenzlaf and Erhardt (1991) observed and increase in Hb concentration and PCV following parenteral administration of iron dextran to lambs which is partially in agreement with the finding of present experiment. The present result is also partially similar to that of Baustad and Tollersrud (1996) who observed an increase in the Hb and PCV values and rise in total RBC count following IM administration of cobalt and iron dextran to calves. Marston et al. (1938) also reported and increase in TEC, Hb and PCV using cobalt and copper supplements in ruminants. 
Haemato-biochemical changes in haematinics treated mice

Table 2. Haemato-biochemical parameters following administration of copper sulphate, ferrous sulphate and vitamin $\mathrm{B}_{12}$ in mice

\begin{tabular}{|c|c|c|c|c|}
\hline \multirow{2}{*}{$\begin{array}{l}\text { Haemato-biochemical } \\
\text { Parameters }\end{array}$} & \multicolumn{4}{|l|}{ Groups $(n=3)$} \\
\hline & $\begin{array}{l}\text { Group A } \\
\left(\mathrm{CuSO}_{4}\right)\end{array}$ & $\begin{array}{l}\text { Group B } \\
\left(\mathrm{FeSO}_{4}\right)\end{array}$ & $\begin{array}{l}\text { Group C } \\
\text { (Vitamin } \mathrm{B}_{12} \text { ) }\end{array}$ & $\begin{array}{l}\text { Group D } \\
\text { (Control) }\end{array}$ \\
\hline TEC (million/mm³) & $* 8.10 \pm 0.12$ & $* 8.30 \pm 0.20$ & $* 8.29 \pm 0.09$ & $7.71 \pm 0.12$ \\
\hline TLC (thousand/mm³) & $10.93 \pm 0.33$ & $10.95 \pm .36$ & $11.2 \pm 0.06$ & $10.87 \pm 0.15$ \\
\hline $\mathrm{Hb}(\mathrm{g} \%)$ & $8.8 \pm 0.23$ & $9.08 \pm 0.34$ & $8.75 \pm 0.43$ & $8.16 \pm 0.20$ \\
\hline $\operatorname{ESR}$ (mm in $1^{\text {st }}$ hour) & 0 & 0 & 0 & 0 \\
\hline PCV $(\%)$ & $* 42.66 \pm 1.15$ & $* 43.66 \pm 1.15$ & $* 43 \pm 1.15$ & $40 \pm 0.57$ \\
\hline SGPT (U/L) & $* 76.05 \pm 0.84$ & $73.05 \pm 0.67$ & $72.89 \pm 0.51$ & $72.72 \pm 0.64$ \\
\hline SGOT (U/L) & 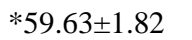 & $53.6 \pm 0.66$ & $53.71 \pm 1.32$ & $53.3 \pm 0.43$ \\
\hline Urea (mg/dl) & **78.33 \pm 1.31 & $49.22 \pm 1.06$ & $* 48.27 \pm 0.61$ & $58.19 \pm 1.84$ \\
\hline
\end{tabular}

*and **indicates significant mean difference from control at the level $5 \%$ and $1 \%$ respectively.

$\mathrm{n}=$ number of blood samples.

SGPT and SGOT of group A increased significantly ( $<0.05)$ compared to control (Table 2). This result is partially in agreement with that of Stangl and Kirchgessner (1998) who observed that iron restriction was accompanied with an accumulation of copper in the liver and increased serum transaminases in rats which are indicative of cell damage. The SGPT and SGOT were also increased for the mice of groups B and C than that of control but it was statistically insignificant. As compared to control, it could be interpreted that blood urea was significantly higher $(\mathrm{p}<0.01)$ for group A and significantly lower $(\mathrm{p}<0.05)$ for group C. The blood urea was also recorded higher for group B but was not significant.

It can be concluded that the data of the present study will be helpful to show the effect of particular haematinics on large animals especially on simple stomach animal and human as mice was used as a human and animal model.

\section{REFERENCES}

1. Baustad B and Tollersrud S (1966). Experiments with injection of cobalt and iron dextran in calves. Medlemsbl. Norske. Vet. Foren 18: 419-423.

2. Chandra S, Chakrabarti A, Sarker S and Dhara K (2000). Anaemia in Black Bengal goats and its chemotherapy. Indian Journal of Animal Health 39 (1): 33-35.

3. Davis GK and Mertz W (1987). Copper, Trace elements in human and animal nutrition. $5^{\text {th }}$ edn., Academic Press, New York. pp. 301-350.

4. Gupta SC (1989). Fundamentals of Statistics. Himalaya Publishing House, New Delhi, India pp. 1222-1224.

5. Lamberg SI and Rothsein R (1977). Laboratory Manual of Haematology and Urinalysis. Avi Publishing Company, Inc. Westport, Connecticut, USA.

6. Martson HR, Lines EWS and Thomas RG (1938). Cobalt and copper in ruminanrs nutrition. American Veterinary Medical Association 90: 171-175.

7. McDonald P, Edwards RA and Greenhalgh JFD (1987). Minerals in country animal Nutrition. $4^{\text {th }}$ edn., English Language Book Society. pp. 106-108.

8. McDowell LR, Conrad JH and Ellis GL (1983). Research in mineral deficiencies for grazing ruminants. Annual Report of AID Mineral Research. University of Florida. USA.

9. Pfander WH (1971). Annual nutrition in the tropics: problems and solution. Journal of Animal Science 33: 834-849.

10. Schonewille JT, Yu S and Beynen AC (1995). High iron intake depresses hepatic copper content in goats. Veterinary Quarterly 17: 14-17.

11. Stangl GI and Kirchgessner M (1998). Effect of different degrees of moderate iron deficiency on the activities of tricarboxylic acid enzymes, and the cytocrome oxidase and the iron copper and zinc contrations in rat tissues. Z. Ernahrungswiss 37 (1-2): 260-268.

12. Sumati W and Kapoor AC (1986). Influence of dietary iron on growth and haemoglobin concentration. Indian Journal of Nutrition and Dieteties 23 (9): 257-261.

13. Wenzlf O and Erhardt G (1991). Effect of parenterally administered iron dextran on erythrocyte parameters and growth rate in lambs of different breeds. Berliner and Munchener Tierarzt Liche Wochen Schrift 103 (7): 239-244. 